\title{
Building Interest in Agricultural Research Trough User Education Activities
}

\author{
Akhmad Syaikhu HS \\ Indonesian Centre for Agricultural Library and Technology Dissemination \\ Indonesian Agency for Agricultural Research and Development \\ Jl. Ir. H. Juanda 20 Bogor, West Java \\ Indonesia \\ asyaikhu@yahoo.com
}

\begin{abstract}
Agriculture is a very important sector in supporting the development of Indonesia. One effort to improve agricultural success is through research and development. Various innovations of technology in agriculture as the result of research and development produced by the Indonesian Agency for Agricultural Research and Development. Agricultural information generated needs to be introduced to the younger generation. For that, the Indonesian Centre for Agricultural Library and Technology Dissemination (ICALTD) sought to create collaborations with schools through user education for students. The materials were packaged in accordance with the level of student understanding in the form of audio-visual and printed materials. These activities are expected to provide an understanding of the importance of agriculture to the development of the nation as well as to foster a sense of interest in the world of research. This paper aims to provide an overview of collaboration between ICALTD and the school in library user education activities, particularly in the field of agriculture.
\end{abstract}

Keywords: User education, Library, Agriculture, Research

\section{Introduction}

Indonesian society has long recognized and applied farming culture. The agricultural sector is very important as one of the major contributing factors in the future development of the nation. But younger generation's interest in agriculture is very low. This indication is based on a study that revealed the average age of farmers ranged from 27 to 82 years old $(67 \%$ are aged over 45 years). Farming is a risky job and requires perseverance, not caring the most about one's appearance, and does not promise to meet basic life needs (Widayadi, 2013). Young people's interest in agriculture may be declining because the government is negligent in utilizing technological advances, and addressing conflicts and psychological development in young people. That's why agriculture should be repositioned as something that is a necessity of life (Goenadi, 2013).

Facing this phenomenon, it is necessary the institution of the Ministry of Agriculture to continue to make efforts to build interest in the younger generation to farm. Indonesian Center Agricultural Library and Technology Dissemination (ICALTD) is one unit of work appropriate for this endeavor. Because ICALTD is an integral part of the Agency for Agricultural Research and Development, one part of its mission is improving information literacy. Providing this service is part of realizing the vision of ICALTD to be a leading and 
reliable information service supporting research and development in agricultural innovation.

ICALTD's mission in improving information literacy to young people is a challenge. Introduction of agricultural research is expected to be one of the efforts ICALTD library undertakes as a means of education. User education programs are an effort of ICALTD to provide education about agricultural information for all people, especially the younger generations. Therefore, the aim of this paper is to provide an overview of the collaboration between the ICALTD and schools in user education programs of agriculture.

\section{Library User Education}

Broadly defined, library user education teaches users how to make the most effective use of the library system (Tiefel, 1995). There are three important objectives: (1) students need to "develop the art of discrimination" to be able to judge the value of books to develop critical judgment; (2) students need to become independent learners - to teach themselves; and (3) students need to continue to read and study - to become lifelong learners. Library user education programs need to support the concept of life-long learning. To achieve these goals, the library and faculty will have to work closely together in developing teaching using the latest technologies (Tiefel, 1995). Information literacy is increasingly recognized as a basic skill in the process of learning and adapting to the changing, living, and working environment of today's information society (Petermanec \& Pejova, 2005).

ICALTD provides user education programs as a form spreading agricultural information. The Agency for Agricultural Research and Development has produced a variety of technological innovations in the agricultural sector. This suggests that research and development is an integral part of agricultural development. Findings are certainly very important because it is valuable knowledge that will be an asset for future generations.

Introduction to agriculture can be taught at any level, from kindergarten to high school. This can encourage the emergence of creativity and dissatisfaction with only buying goods (Goenadi, 2013). One way to raise children to love the farm is to teach local wisdom that has been done when the ancestors farmed (Putranto, 2013). Indigenous knowledge or local wisdom is an accumulation of collective experience from generation to generation. It needs to be developed to enrich and complete the assembly of agricultural technology innovation for a sustainable future. Ultimately, this will result in new discoveries, innovations, and applications (Noor, \& Jumberi, 2007).

\section{Collaboration ICALTD and School}

ICALTD builds collaboration with schools in the city of Bogor and its surroundings in order to facilitate the delivery of user education programs. This collaboration aims to provide an opportunity for the school to gain agricultural information. Schools can utilize the facilities and library collections in teaching and learning so that students can acquire additional knowledge in the field of agriculture. Collaboration with the school is essential in supporting the learning process. In education, collaboration reflects a shifting philosophical view about the importance of working together to improve learning (Montiel-Overall, 2005).

ICALTD is using the concept of user education in collaboration with the school. In user education, ICALTD adopted the collaboration Model B: Cooperation. In this model, the teachers and librarians begin to work more closely to enhance students' learning opportunities (Figure 1). Teachers and librarians cooperate on lessons or units of study by dividing tasks. Goals and objectives are developed independently, although joint instruction may also be involved (Montiel-Overall, 2005).
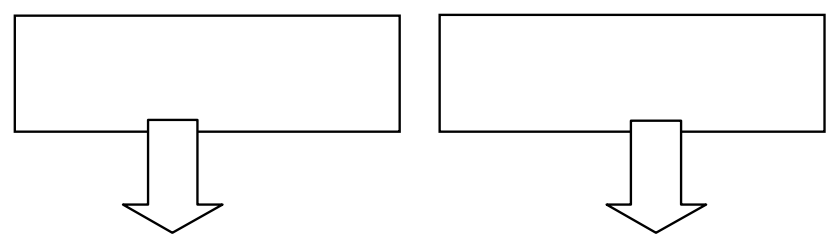

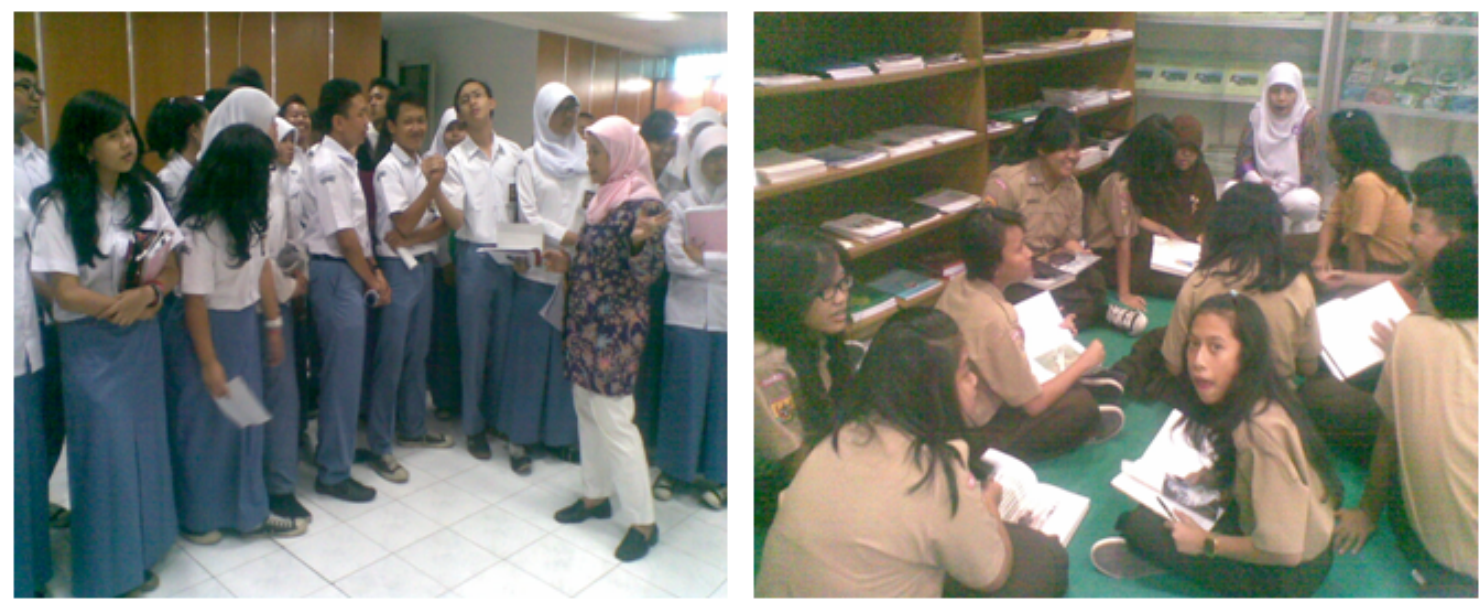

Figure 3: Activites at ICATLD open house
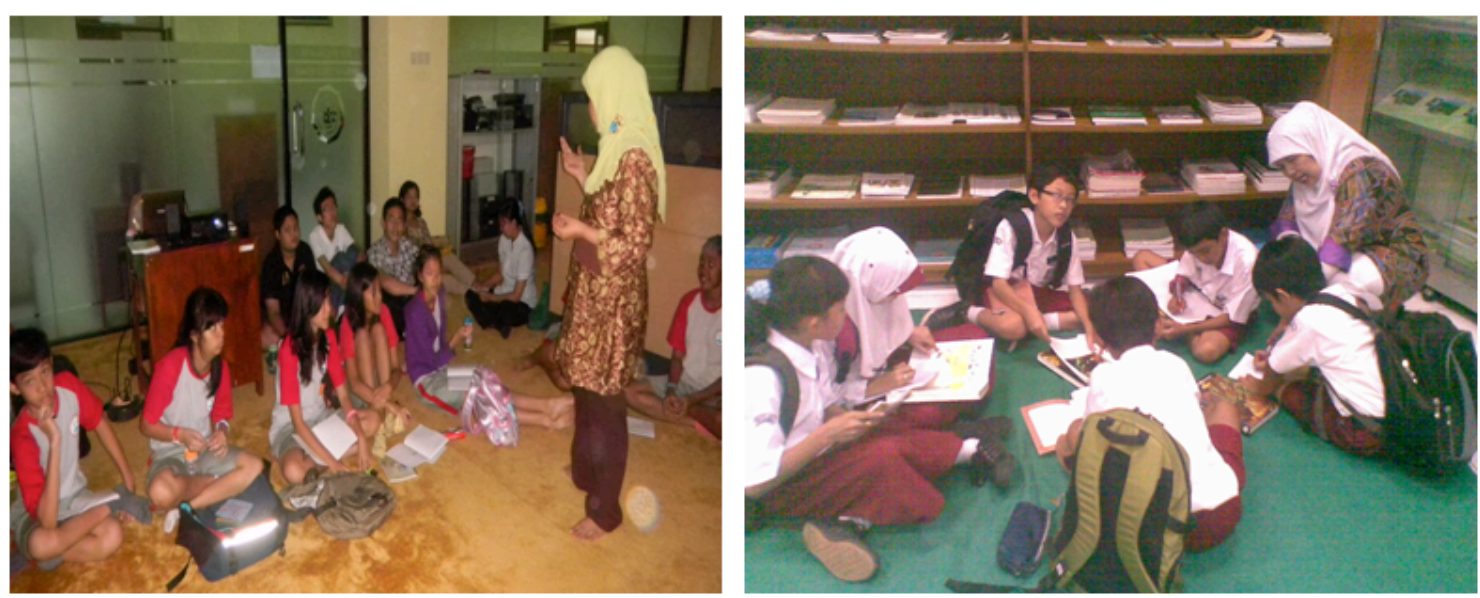

Figure 4: Activities at User Education Programs

\section{Conclusion}

User education in agriculture is expected to revive the younger generation's interest in farming. The results certainly are not going to be instantaneous, but in the future they will develop innovative agricultural technology so that the agricultural sector will remain a resource for national development. ICALTD will certainly continue to increase the interest of the younger generation in agriculture through collaboration with the world of education.

\section{References}

Goenadi, D.H. (2013). Peneliti harus kreatif dan fokus. Majalah Sains Indonesia, 17(Mei), 15-17.

Montiel-Overall, P. (2005). A theoretical understanding of teacher and librarian collaboration (TLC). School Libraries Worldwide, 11(2), 24-48.

Noor, M \& Jumberi, A. (2007). Kearifan Budaya Lokal dalam Perspektif di Lahan Rawa. [in] Kearifan Budaya Lokal dalam Perspektif di Lahan Rawa. BALITTRA : Banjarbaru

Petermanec, Z., \& Pejova, Z. (2005). User education and forms of information literacy education and training at the universities in Slovenia. Knjižnica, 49(4), 51-76 
Putranto, Y. (2013). Sentuhan inovasi antarkan petani sukses. Majalah Sains Indonesia, 17(Mei), 12-14.

Tiefel, V. M. (1995). Library user education; examining its past, projecting its future.Library Trends, 44(2), 318-383

Widayadi, S. (2013). Kita (tak) butuh petani!. Majalah Sains Indonesia, 17(Mei), 6-11.

\section{Biographical note}

Name

Affiliation

Address

Place/Date of birth

Email
Akhmad Syaikhu HS., S.Sos. (initials : SYAIKHU)

Indonesian Center for Agricultural Library and

Technology Dissemination

JI. Ir. H. Juanda No. 20 Bogor 16122

Tegal/June, $25^{\text {th }} 1974$

asyaikhu@yahoo.com 